\title{
APOE genetic variants and apoE, miR-107 and miR-650 levels in Alzheimer's disease
}

\author{
Michal Prendecki ${ }^{1}$, Jolanta Florczak-Wyspianska ${ }^{2}$, Marta Kowalska $^{1}$, Jan Ilkowski ${ }^{3}$, Teresa Grzelak ${ }^{4}$, \\ Katarzyna Bialas ${ }^{1}$, Wojciech Kozubski², Jolanta Dorszewska ${ }^{1}$ \\ ${ }^{1}$ Laboratory of Neurobiology, Department of Neurology, Poznan University of Medical Sciences, Poznan, Poland, ${ }^{2}$ Chair and \\ Department of Neurology, Poznan University of Medical Sciences, Poznan, Poland, ${ }^{3}$ Department of Emergency Medicine, Poznan \\ University of Medical Sciences, Poznan, Poland, ${ }^{4}$ Chair and Department of Physiology, Poznan University of Medical Sciences, \\ Poznan, Poland
}

\begin{abstract}
Alzheimer's disease $(A D)$ is a progressive neurodegenerative dementia in adults. Pathogenesis of $A D$ depends on various factors, including APOE genetic variants, apolipoprotein $E$ (apoE) phenotype and oxidative stress, which may promote both DNA and RNA damage, including non-coding RNA (nCRNA). Among nCRNAs, microRNA (miRNA) is known to contribute to pathologic processes in $A D$.

The aim of the study was to analyse the plasma concentration of apoE by ELISA as well as the plasma levels of miR-107 and miR-650 by qPCR in relation to APOE genetic variants and clinical features including the age of onset and dementia severity in $64 A D$ patients and 132 controls.

Our data showed that a low apoE plasma concentration was a risk factor for developing $A D(O R=5.18, p=6.58 E-06)$ and was particularly pronounced in severe dementia $(p<0.001)$ and correlated with cognitive functions $(R=0.295$, $p=0.020)$, similarly as the level of miR-650 $(R=0.385, p=0.033)$.

The presence of $A P O E E 4$ allele in both $A D$ patients and controls led to a reduction in apoE, while APOE E3/E3 genotype was associated with an increased apoE concentration and level of miR-107 in $A D(p<0.05)$ which was inversely correlated with the number of APOE E4 alleles $(R=-0.448, p=0.009)$. Additionally, patients with the onset at 60-69 years of age showed a reduced level of miR-107 ( $p<0.05$, as compared to $A D$ above 80 years of age).

Changed levels of plasma apoE, miR-107 and miR-650 may be a marker of the neurodegenerative process in the course of $A D$, associated with amyloid $\beta$ metabolism and inordinate cell cycle.
\end{abstract}

Key words: APOE, apoE, miRNA, miR-107, miR-650, Alzheimer's disease.

\section{Introduction}

Alzheimer's disease (AD) is a progressive, age-dependent disease characterized by accumulation of $\beta$-amyloid $(A \beta)$ [2] which is quickly cleared with help of apolipoprotein $E$ (apoE). ApoE is encod- ed by the $A P O E$ gene, located on chromosome 19. Our previous studies pointed out that the apoE level may vary in healthy individuals before 60 years of age depending on $A P O E$ genetic status and age or gender of subjects [50]. The APOE locus houses

\section{Communicating author}

Prof. Jolanta Dorszewska, MDs, PhD, Laboratory of Neurobiology, Department of Neurology, Poznan University of Medical Sciences, 49 Przybyszewskiego St., 60-355 Poznan, Poland, phone: +48 618691 439, fax: +48 6186 91 697, e-mail: dorszewskaj@yahoo.com 
two well-known polymorphisms, the rs7412 and rs429358 whose variants distinguish three common $A P O E$ alleles: protective $\mathrm{E} 2$, neutral, most common in population E3 and pathogenic E4. APOE E4 has a multidimensional impact on pathogenesis of $A D$, including dysregulation of lipids and lipoproteins, such as apoE plasma level [52], as well as decreased $\mathrm{A} \beta$ clearance and glucose metabolism, reduced neuronal signalling, enhanced neuroinflammation and mitochondrial dysfunction [37,40], and additionally elevated oxidative stress [8]. Previous studies have shown that the changes in oxidative stress regulation mechanisms may be strongly associated with the development and onset of $A D$ as well as with the changes in the level of oxidative damage in DNA (such as 8-oxo-2'deoxyguanosine, 8-oxo2dG) or levels of biothiols (such as homocysteine - Hcy, and glutathione - GSH) [9,49] and with alterations in p53 protein activity $[38,41]$, both in blood cells and plasma [47]. The prolonged oxidative stress, besides DNA damage, may cause also RNA damage [5] and affect the expression on the RNA level, including changes of microRNA (miRNA) [48], e.g. hsa-miR107-5p (miR-107, MIMAT0000104) [73]. MiR-107 is managed by soluble $A$ [35] and engaged in regulation of its production $[21,71]$. So far, the miR-107 has not been correlated with apoE or other biochemical markers, what is more such studies have not been performed yet in Polish AD patients.

There are ongoing studies searching for specific miRNAs to explain the pathogenesis of $A D$ and to improve the effectiveness of treatment, especially in patients with an increased predisposition to earlier manifestation of the disease, particularly in the APOE E4 carriers, in whom the apoE expression is decreased. It remains unknown whether the apoE individual variation results from the genetic predisposition [27] or rather from the posttranslational modulation by miRNA. We applied bioinformatics tools to predict whether the miRNAs might potentially affect the production of apoE and we have found a promising target, hsa-miR-650-5p (miR-650, MIMAT0003320), previously detected in the brain and associated with various neoplasms [75], including glioblastoma [65]. So far, this miRNA has not been studied in degenerative diseases, such as AD.

In the present study, the authors tried to determine the apoE concentration as well as the levels of miR-107 and miR-650 in plasma of Polish AD patients and controls. The study also investigated whether these biochemical parameters correlate with $A P O E$ genetic variants. Additionally, the analysis of clinical features including age of onset and severity of dementia symptoms according to MMSE scale in $A D$ patients was performed in relation to $A P O E$ genotypes, apoE plasma level as well as measured miRNAs.

\section{Material and methods}

We recruited 196 subjects, including 64 AD patients diagnosed by a trained neurologist according to NINCDS-ADRDA criteria [16] (mean age 76.0 years, $68.8 \%$ females); and 74 control volunteers over 60 years of age with no signs of dementia and other neurological disorders or family history of $A D$ (UC, mean age: 71.4 years, $78.4 \%$ females) and 58 volunteers aged over 60 years with a positive family history of $A D$ and no signs of dementia or other neurological diseases, as a comparative group (RC, mean age: 65.5 years, $70.7 \%$ females). For all participants we analysed the APOE genetic status.

The peripheral blood was drawn from all subjects, fasting for at least 12 hours, by S-Monovette system (Sarstedt, Germany) with $\mathrm{K}_{3}$ EDTA as anticoagulant for plasma isolation and subsequent apoE and miRNA analysis.

ApoE quantification in $K_{3}$ EDTA plasma was performed by the ELISA method (MABTECH, Sweden) on EPOCH spectrophotometer (Bio-TEK, USA), as previously described [50].

\section{RNA isolation}

$100 \mu \mathrm{l}$ of plasma was mixed with $1 \mathrm{ml}$ of RNA Extracol (EURx, Poland) and $5 \mu$ of spike-in miRNA standard (5 nM solution of cel-miR-39-3p, MIMAT0000010; Genesius, Poland) until homogeneity. Next, $200 \mu \mathrm{l}$ of chloroform (POCH, Poland) was added and mixed. After 5 min incubation, the samples were centrifuged at $4^{\circ} \mathrm{C}$ and $500 \mu$ l of the aqueous phase was mixed with $5 \mu$ of GlycoBlue Coprecipitant $(15 \mu \mathrm{g} / \mathrm{ml}$; ThermoFisher Scientific, USA). RNA was precipitated with $505 \mu \mathrm{l}$ of isopropanol (POCH, Poland) and incubated at $-20^{\circ} \mathrm{C}$ for $20 \mathrm{~min}$, followed by centrifugation at $4^{\circ} \mathrm{C}$. The pellet was washed twice with ice cold $75 \% \mathrm{EtOH}$ (Merk, Germany), air dried and dissolved in $10 \mu$ of Milli-Q water supplied with $1 \mathrm{U} / \mu \mathrm{l}$ RNase inhibitor (A\&A Biotechnology, Poland). The benchtop isolation stages were performed on ice. 


\section{MiRNAs analysis}

We applied $2 \mu \mathrm{l}$ of isolated RNA for simultaneous single tube polyadenylation/reverse transcription reaction ( $P A-R T, 0.3 \cup$ Poly-A polymerase, EURx; $40 \mathrm{U}$ of TranScriba MMLV reverse transcriptase, $10 \mathrm{U}$ of RNase inhibitor; A\&A Biotechnology, Poland) with the mixture of $0.5 \times$ Poly-A and $0.5 \times$ MMLV reaction buffers, supplemented with $\mathrm{MnCl}_{2}$, dNTPs and 3'RACE adaptor as primer (Genesius, Poland; final concentrations: $1.9 \mathrm{mM}, 1 \mathrm{mM}$ and $0.5 \mu \mathrm{M}$, respectively) in volume of $10 \mu$, on ice. The obtained cDNA was diluted to $200 \mu \mathrm{l}$ with Milli-Q water and $2 \mu \mathrm{l}$ was used for qPCR assessment of miRNAs relative content using complementary DNA primers (final concentration $0.25 \mathrm{nM}$ ) and $1 \times$ SsoFast EvaGreen Supermix (BIO-RAD, USA) in final volume of $10 \mu$ l on CFX-Connect Real-Time System (BIO-RAD, USA), as previously reported [3]. Oligos' sequences and cycling conditions are shown in Tables I and II. The Ct values and relative abundance of circulating plasma miRNAs were calculated with respect to spike-in RNA standard by $\Delta$ Ct method, as described before [54].

\section{Statistical analyses}

Statistical analyses were performed using GraphPad for Windows software and Statistica 12 for Windows software (StatSoft, USA), with the nonparametric tests (Kruskal-Wallis test and Mann-Whitney test), unless stated otherwise. The normality of data distributions was checked using the Shapiro-Wilk test (when the sample size was 50 or less) and Kolmogorov-Smirnov (when the sample size was larger

Table I. The sequences of primers used for reverse transcription (3'RACE adaptor) and for microRNAs real-time qPCR assessment (celmiR-39-3p - cel-miR; hsa-miR-107-5p - miR107; hsa-miR-650-5p - miR-650 and universal reverse primer)

\begin{tabular}{|cc|}
\hline $\begin{array}{c}\text { Primers' } \\
\text { name }\end{array}$ & Primers' sequence \\
\hline $\begin{array}{c}\text { 3'RACE } \\
\text { adaptor }\end{array}$ & $\begin{array}{c}\text { 5'-GCGAGCACAGAATTAATACGACTCACTATAGG } \\
\text { TTTTTTTTTTTVN-3' } \\
\text { where } V=\text { A, G, C; } N=\text { A, T, G, C }\end{array}$ \\
\hline cel-miR & 5'-TCACCGGGTGTAAATCAGCTTG-3' \\
\hline miR-107 & 5'-AGCAGCATTGTACAGGGCTATCA-3' \\
\hline miR-650 & 5'-AGGAGGCAGCGCTCTCAGGAC-3' \\
\hline universal & 5'-GCGAGCACAGAATTAATACGACTCA-3' \\
\hline
\end{tabular}

than 50). Analysis of the homogeneity of variance was carried out using the Levene's test. The level of significance was set at $p<0.05$. The associations were assessed by Spearman's correlation coefficient, with the level of significance set at $p<0.05$.

\section{Results}

The current study showed that in the course of $A D$, the median apoE concentration in plasma was decreased by $28.7 \%$ and $49.2 \%$ as compared to UC and RC, respectively. Moreover, the authors observed that $62.5 \%$ of AD patients had a reduced apoE concentration ( $<1.315 \mathrm{mg} / \mathrm{dl}-1^{\text {st }}$ quartile for UC, Table III) as compared to $24.3 \%$ of UC and only $10.3 \%$ of RC $(\mathrm{OR}=5.18, p=6.58 \mathrm{E}-06$ and $\mathrm{OR}=14.4, p<1.00 \mathrm{E}-8)$.

Subsequently, the lowest recorded apoE median concentration was observed in AD patients, homozygous carriers of APOE E4/E4 allele while the homozygous E3/E3 carriers had the highest apoE median concentration among all groups, except UC where the highest concentration was observed in single homozygous E2/E2 genotype carrier (Table IV).

The present study has also shown that the median concentration of apoE may be associated with age of onset of AD. The lowest apoE levels were recorded in patients with late onset disease (e.g. $7^{\text {th }}$ decade of life) while in persons with higher apoE levels,

Table II. Cycling conditions for one-tube-polyadenylation-reverse transcription reaction (PA-RT) and real-time qPCR for cel-miR-39-3p (cel-miR), hsa-miR-107-5p (miR-107) and hsa-miR-650-5p (miR-650)

\begin{tabular}{|c|c|c|}
\hline Temperature & Time & No. of repeats \\
\hline \multicolumn{3}{|c|}{ One-tube-polyadenylation-reverse transcription (PA-RT) } \\
\hline $4^{\circ} \mathrm{C}$ & 00:01:00 & n.a. \\
\hline $37^{\circ} \mathrm{C}$ & $00: 45: 00$ & \\
\hline $42^{\circ} \mathrm{C}$ & 01:00:00 & \\
\hline $75^{\circ} \mathrm{C}$ & 00:05:00 & \\
\hline $4^{\circ} \mathrm{C}$ & $\infty$ & \\
\hline \multicolumn{3}{|c|}{ Real-time qPCR for cel-miR, miR-107 and miR-650 } \\
\hline $95^{\circ} \mathrm{C}$ & 00:01:30 & $1 \times$ \\
\hline $95^{\circ} \mathrm{C}$ & 00:00:10 & $40 x$ \\
\hline $64^{\circ} \mathrm{C}$ & 00:00:06 & \\
\hline $95^{\circ} \mathrm{C}$ & 00:00:30 & $1 \times$ \\
\hline $60 \rightarrow 95^{\circ} \mathrm{C}^{*}$ & $\uparrow 0.3^{\circ} \mathrm{C}$ every $3 \mathrm{sec}^{*}$ & $117 \times$ \\
\hline $4^{\circ} \mathrm{C}$ & $\infty$ & n.a. \\
\hline
\end{tabular}

*Melting curve analysis 
Table III. The concentration of apolipoprotein E (apoE) and relative level of microRNAs: hsa-miR-107-5p (miR-107), hsa-miR-650-5p (miR-650) in plasma of Alzheimer's disease (AD) patients and related controls (RC), and unrelated controls (UC)

\begin{tabular}{|c|c|c|c|c|c|c|c|}
\hline \multirow[t]{2}{*}{ Parameters } & \multirow{2}{*}{$\begin{array}{l}\text { Unrelated } \\
\text { controls } \\
\text { (UC) }\end{array}$} & \multirow{2}{*}{$\begin{array}{c}\text { Related } \\
\text { controls (RC) }\end{array}$} & \multirow{2}{*}{$\begin{array}{l}\text { Alzheimer's } \\
\text { disease } \\
\text { (AD) }\end{array}$} & \multicolumn{4}{|c|}{$p$} \\
\hline & & & & $\begin{array}{l}\text { AD vs. UC } \\
\text { vs. RC }\end{array}$ & AD vs. UC & $A D$ vs. $R C$ & UC vs. RC \\
\hline apoE [mg/dl] & $\begin{array}{c}1.628 \\
{[1.315-2.097]}\end{array}$ & $\begin{array}{c}2.285^{\star * \star} \\
{[1.614-2.846]}\end{array}$ & $\begin{array}{c}1.161^{* * *}\left({ }^{* * *}\right) \\
{[0.8405-1.595]}\end{array}$ & $0.0053^{\#}$ & $6.61 \mathrm{E}-06^{\circledR}$ & $6.38 \mathrm{E}-13^{\circledR}$ & $3.80 \mathrm{E}-05^{@}$ \\
\hline miR-107 [R.U.] & $\begin{array}{c}0.9179 \\
{[0.6307-1.304]}\end{array}$ & $\begin{array}{c}0.9727 \\
{[0.5415-1.255]}\end{array}$ & $\begin{array}{c}0.8827 \\
{[0.6146-1.240]}\end{array}$ & $0.8199^{\#}$ & $0.7786^{@}$ & $0.7328^{@}$ & 0.5448 \\
\hline miR-650 [R.U.] & $\begin{array}{c}0.8135 \\
{[0.4130-1.268]}\end{array}$ & $\begin{array}{c}0.5614 \\
{[0.4188-0.8701]}\end{array}$ & $\begin{array}{c}0.6152 \\
{[0.4031-1.220]}\end{array}$ & $0.5148^{\#}$ & $0.7867^{@}$ & 0.5179@ & 0.2308 \\
\hline
\end{tabular}

Median [1 $1_{-}^{\text {st }} 3^{\text {rd }}$ quartile]; ${ }^{\#}$ Kruskal-Wallis test; $@$ Mann-Whitney test; ${ }^{* * *} p<0.001$, as compared to unrelated controls, $\left({ }^{* * *}\right) p<0.001$ as compared to related controls; R.U. - relative units

the disease developed at even older age (> 80 years), as shown in Table $\mathrm{V}$.

The authors observed also a decrease in the apoE median level with advancement of the disease (measured in MMSE scale, $R=0.295, p=0.020$, Spearman correlation coefficient - SCC). We recorded a $14.6 \%$ decrease in preclinical AD (mild cognitive impairment $-\mathrm{MCl}$ ) as well as a $20.8 \%$ and $23.8 \%$ reduction in mild and moderate dementia, respectively. The patients with severe dementia showed even further reduction in the apoE level (48.2\%, as compared to UC and $39.4 \%$ as compared to $\mathrm{MCI}$ ), as shown in Table VI.

In the present study, the authors observed a tendency for a decreased median concentration of miR107 in AD patients as compared to both RC and UC. Interestingly, the difference was more pronounced as compared to related controls (Table III).

In the current work, for the first time, it has been shown that miR-107 level may be associated with the $A P O E$ genotype. In $A D$, a reverse correlation between the number of $A P O E$ E4 alleles and the level of miR-107 ( $R=-0.448, p=0.009$, SCC) was observed. In APOE E3/E3 AD carriers a significantly increased miR-107 level was measured as compared to both related and unrelated controls (Table IV).

Moreover, the present study showed that the level of miR-107 was significantly associated with age of onset of AD. The authors observed a significant reduction in miR-107 in patients who developed $A D$ at the age of 60-69 years old $(p=0.036)$ and reverse tendency in patients who developed $A D$ at old age ( $p>0.05$; age $>80$ years, Table V). Additionally, the most reduced median level of miR-107 was observed in severe dementia $(p>0.05$, Table VI).
The present data revealed a tendency for a decreased median miR-650 level in AD patients as well as in RC as compared to UC ( $p>0.05$; Table III).

The authors observed a significant correlation between the severity of dementia and the level of miR-650 ( $R=0.385, p=0.033, \mathrm{SCC})$. The lowest miR650 levels were observed in patients with severe dementia, with a $58.6 \%$ reduction of median as compared to UC ( $p=0.091$, Table VI).

\section{Discussion}

The pathogenesis of $A D$ is currently explained by various hypotheses, including mitochondrial dysfunction [40], immunological disturbances, augmented oxidative stress, and amyloid cascade associated with $A \beta$ deposition [14]. Due to years of research, which did not contribute to development of new drugs, recently the $A \beta$ hypothesis grew less popular in favour of a multidirectional approach [6]. Supporters of the central role of amyloid cascade claim that in the $A D$ brain the formation of the $A \beta$ plaques precedes the NFT formation and is especially marked in people with unfavourable APOE variants, coding for different apoE isoforms [14].

In 2018, the National Institute on Aging and the Alzheimer's Association presented the research framework [44] that similarly as the Erlangen Score Algorithm [19,28] did not officially include apoE as AD biomarker, probably due to contradicting results regarding its function in animal models [4,24] and diverse data on apoE level in human AD pathology [27]. There are studies performed on peripheral blood drawn from $A D$ patients, demonstrating elevated $[26,62,66]$, unchanged $[11,32,39,46,53,57,61]$ and reduced apoE levels $[18,20,29,30,36,52,55,60,68]$ in 


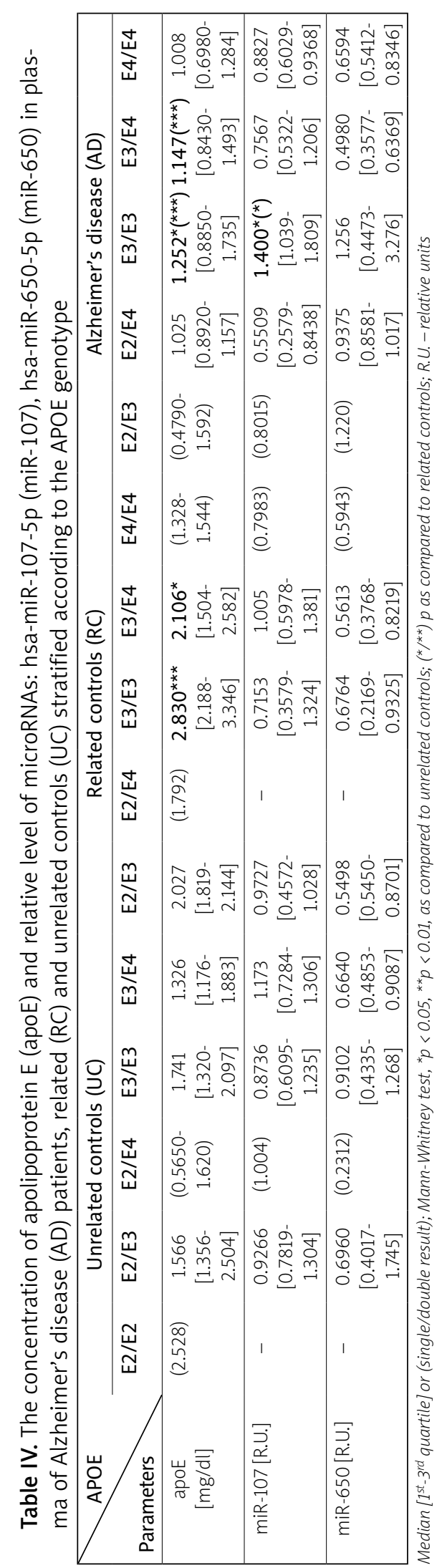

the course of this neurodegenerative disease. The present study showed a reduction in plasma apoE concentration in $A D$ patients, associated with disease advancement. The similar results were presented by Gupta et al. [22], Rasmussen et al. [51] and Wolters et al. [72].

At the same time, it was shown that a reduced level of apoE may result from the APOE polymorphisms [36] and oxidative modifications in the course of $A D$ [1]. Moreover, the reduced apoE concentration may impair $A \beta$ removal from the central nervous system (CNS) and may decrease its level in cerebrospinal fluid (CSF) [64], as shown by Hu et al. [25] who demonstrated that a reduction in $A \beta$ levels was associated with an increase in T-tau/A $\beta$ ratio and $A P O E$ E4 allele. A reduced level of $A \beta$ in CSF is associated with the accumulation of $A \beta$ plaques [17] and oligomers, which may generate reactive oxygen species (ROS) [23]. Increased production of ROS leads to damage of macromolecular compounds, among others, DNA in the form of 8-oxo2dG [10] and impaired efficiency of the repairing enzyme 8-oxoguanine glycosylase (OGG1). This dependence seems to be confirmed by the correlation obtained in our study, between the plasma concentrations of apoE and the marker of oxidative damage (8-oxo2dG) and its repair enzyme (OGG1) observed only in physiological conditions (UC, $R=0.314, p=0.008$ and $R=0.328, p=0.005$, respectively, SCC) and most likely impaired in $A D$ patients and in persons with a positive family history of AD $(p>0.05)$ [49].

It has been shown that in $A D$, not only DNA, but also RNA and miRNA may undergo oxidation, and form of 8-oxo-Gua [5], which could be subsequently repaired by base excision (BER) enzymes [31]. In addition, oxidized miRNA may lose or acquire new functions, e.g. proapoptotic activity by miR-184 [69]. It would seem that the oxidative damage could also affect other miRNAs in AD. The literature data and our study showed that the levels of miR-107 were significantly reduced in the course of $A D[34,70,74]$. The changes of peripheral miR-107 probably reflect its fluctuations in the brain [71] where the reduced content of miR-107 augments the activity of betasite cleaving enzyme (BACE1, an active subunit of $\beta$-secretase) involved in amyloid cascade, and thus promotes $A \beta$ production [43]. MiR-107 may be also associated with regulation of cell cycle via p53 protein. According to Chen et al. [7], the level of miR-107 is reduced in p53 mutated cell lines. Moreover, muta- 
Table V. The concentration of apolipoprotein $E$ (apoE) and relative level of microRNAs: hsa-miR-107-5p, hsamiR-650-5p in plasma of Alzheimer's disease (AD) patients stratified according to the age of onset (years)

\begin{tabular}{|c|c|c|c|c|c|c|c|c|c|c|}
\hline \multirow[t]{2}{*}{$\begin{array}{l}\text { Para- } \\
\text { meter }\end{array}$} & \multirow{2}{*}{$\begin{array}{l}\text { Unrelated } \\
\text { controls } \\
\text { (UC) }\end{array}$} & \multirow{2}{*}{$\begin{array}{c}\text { Related } \\
\text { controls } \\
(\mathrm{RC})\end{array}$} & \multicolumn{4}{|c|}{$\begin{array}{l}\text { Alzheimer's disease (AD) } \\
\text { Age of onset [years] }\end{array}$} & \multicolumn{4}{|c|}{$p$ values } \\
\hline & & & $<60$ & $60-69$ & $70-79$ & $>80$ & & vs. UC@ & vs. RC@ & vs. $>80^{@}$ \\
\hline \multirow{2}{*}{$\begin{array}{c}\text { apoE } \\
{[\mathrm{mg} / \mathrm{dl}]}\end{array}$} & \multirow{2}{*}{$\begin{array}{c}1.628 \\
{[1.315} \\
-2.097]\end{array}$} & \multirow{2}{*}{$\begin{array}{c}2.285 \\
{[1.614} \\
-2.846]\end{array}$} & \multirow{2}{*}{$\begin{array}{l}(1.592- \\
2.894)\end{array}$} & \multirow{2}{*}{$\begin{array}{c}1.234^{\star \star}\left({ }^{\star \star \star}\right) \\
{[0.795-} \\
1.498]\end{array}$} & \multirow{2}{*}{$\begin{array}{l}1.190^{* * *}(* * *) \\
{[0.838-1.596]}\end{array}$} & \multirow{2}{*}{$\begin{array}{c}1.396\left(^{*}\right) \\
{[1.119-} \\
2.204]\end{array}$} & K-W & \multicolumn{2}{|c|}{$p<0.0001^{\$}$} & $p=0.1172^{\#}$ \\
\hline & & & & & & & $\begin{array}{c}60-69 \\
70-79 \\
>80\end{array}$ & $\begin{array}{c}0.0021 \\
6.00 \mathrm{E}-05 \\
0.6070\end{array}$ & $\begin{array}{c}1.00 \mathrm{E}-06 \\
1.00 \mathrm{E}-07 \\
0.0149\end{array}$ & $\begin{array}{c}0.1747 \\
0.0955 \\
-\end{array}$ \\
\hline \multirow{2}{*}{$\begin{array}{l}\text { miR- } \\
107 \\
{[\text { R.U.] }}\end{array}$} & \multirow{2}{*}{$\begin{array}{c}0.9179 \\
{[0.6307} \\
-1.304]\end{array}$} & \multirow{2}{*}{$\begin{array}{c}0.9727 \\
{[0.5415-} \\
1.255]\end{array}$} & \multirow{2}{*}{$\begin{array}{c}(0.8015- \\
1.809)\end{array}$} & \multirow{2}{*}{$\begin{array}{c}0.7449\left[^{\star}\right] \\
{[0.4031-} \\
1.373]\end{array}$} & \multirow{2}{*}{$\begin{array}{c}0.9969 \\
{[0.5885-} \\
1.324]\end{array}$} & \multirow{2}{*}{$\begin{array}{c}1.263 \\
{[1.161-} \\
1.559]\end{array}$} & K-W & \multicolumn{2}{|c|}{$p=0.4632^{5}$} & $p=0.2248^{\#}$ \\
\hline & & & & & & & $\begin{array}{c}60-69 \\
70-79 \\
>80\end{array}$ & $\begin{array}{l}0.1579 \\
0.9777 \\
0.2902\end{array}$ & $\begin{array}{l}0.4053 \\
0.7346 \\
0.1957\end{array}$ & $\begin{array}{c}0.0360 \\
0.4940 \\
-\end{array}$ \\
\hline \multirow{2}{*}{$\begin{array}{c}\text { miR- } \\
650 \\
\text { [R.U.] }\end{array}$} & \multirow{2}{*}{$\begin{array}{c}0.8135 \\
{[0.4130} \\
-1.268]\end{array}$} & \multirow{2}{*}{$\begin{array}{c}0.5614 \\
{[0.4188-} \\
0.8701]\end{array}$} & \multirow{2}{*}{$\begin{array}{c}(0.2706- \\
1.220)\end{array}$} & \multirow{2}{*}{$\begin{array}{c}0.6369 \\
{[0.6029-} \\
0.8827]\end{array}$} & \multirow{2}{*}{$\begin{array}{c}0.5917 \\
{[0.4980-} \\
1.008]\end{array}$} & \multirow{2}{*}{$\begin{array}{c}0.7179 \\
{[0.3437-} \\
2.892]\end{array}$} & K-W & \multicolumn{2}{|c|}{$p=0.9166^{\$}$} & $p=0.9833^{\#}$ \\
\hline & & & & & & & $\begin{array}{c}60-69 \\
70-79 \\
>80\end{array}$ & $\begin{array}{l}0.9710 \\
0.7862 \\
1.0000\end{array}$ & $\begin{array}{c}0.6266 \\
0.4764 \\
0.8153\end{array}$ & $\begin{array}{c}0.8639 \\
0.8411 \\
- \\
\end{array}$ \\
\hline
\end{tabular}

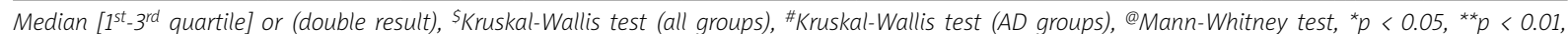
as compared to UC, ${\left({ }^{*} / * *\right)}^{*}$ as compared to $R C ;\left[{ }^{*}\right] p$ as compared to $A D$ with onset $>80$ years; $R$.U. - relative units

Table VI. The concentration of apolipoprotein E (apoE) and relative level of microRNAs: hsa-miR-107-5p, hsa-miR-650-5p in plasma of Alzheimer's disease (AD) patients stratified according to dementia severity according to MMSE scale [0-30 points] and related (RC), and unrelated controls (UC)

\begin{tabular}{|c|c|c|c|c|c|c|c|c|c|c|}
\hline \multirow{2}{*}{ Parameter } & \multirow{2}{*}{$\begin{array}{c}\text { UC } \\
{[30-27]}\end{array}$} & \multirow{2}{*}{$\begin{array}{c}R C \\
{[30-27]}\end{array}$} & \multirow{2}{*}{$\begin{array}{c}\mathrm{MCl} \\
{[26-24]}\end{array}$} & \multirow{2}{*}{$\begin{array}{c}\text { Mild } \\
{[23-19]}\end{array}$} & \multirow{2}{*}{$\begin{array}{c}\text { Mod } \\
{[18-11]}\end{array}$} & \multirow{2}{*}{$\begin{array}{c}\mathrm{Sev} \\
{[10-0]}\end{array}$} & \multicolumn{4}{|c|}{$p$ values } \\
\hline & & & & & & & K-W & Group & vs. UC@ & vs. RC@ \\
\hline apoE [mg/dl] & $\begin{array}{l}1.628 \\
{[1.315-} \\
2.097]\end{array}$ & $\begin{array}{l}2.285 \\
{[1.614-} \\
2.846]\end{array}$ & $\begin{array}{c}1.391\left(^{\star}\right) \\
{[0.7530-} \\
1.592]\end{array}$ & $\begin{array}{c}1.290^{*}(* * *) \\
{[0.944-} \\
1.794]\end{array}$ & $\begin{array}{c}\left.1.240^{\star *(* * *}\right) \\
{[0.9775-} \\
1.595]\end{array}$ & $\begin{array}{c}0.843^{* * *}(* * *) \\
{[0.6460-} \\
1.161]\end{array}$ & $\begin{array}{c}<0.0001^{\$} \\
0.0599^{\#}\end{array}$ & $\begin{array}{l}\text { MCl } \\
\text { Mild } \\
\text { Mod } \\
\text { Sev }\end{array}$ & $\begin{array}{c}0.1943 \\
0.0314 \\
0.0017 \\
1.80 \mathrm{E}-05\end{array}$ & $\begin{array}{c}0.0199 \\
4.40 \mathrm{E}-06 \\
7.97 \mathrm{E}-08 \\
2.18 \mathrm{E}-07\end{array}$ \\
\hline $\begin{array}{c}\text { miR-107 } \\
\text { [R.U.] }\end{array}$ & $\begin{array}{c}0.9179 \\
{[0.6307-} \\
1.304]\end{array}$ & $\begin{array}{c}0.9727 \\
{[0.5415-} \\
1.255]\end{array}$ & $\begin{array}{c}(0.6763- \\
0.8015)\end{array}$ & $\begin{array}{c}1.1833 \\
{[0.8633-} \\
1.442]\end{array}$ & $\begin{array}{c}0.8586 \\
{[0.2975-} \\
1.093]\end{array}$ & $\begin{array}{c}0.7647 \\
{[0.6385-} \\
1.297]\end{array}$ & $\begin{array}{l}0.5251^{\$} \\
0.1257^{\#}\end{array}$ & $\begin{array}{l}\text { MCl } \\
\text { Mild } \\
\text { Mod } \\
\text { Sev }\end{array}$ & $\begin{array}{c}- \\
0.2878 \\
0.2554 \\
0.7210\end{array}$ & $\begin{array}{c}- \\
0.1724 \\
0.4736 \\
0.9822\end{array}$ \\
\hline $\begin{array}{c}\text { miR-650 } \\
\text { [R.U.] }\end{array}$ & $\begin{array}{c}0.8135 \\
{[0.4130-} \\
1.2675]\end{array}$ & $\begin{array}{c}0.5614 \\
{[0.4188-} \\
0.8701]\end{array}$ & $\begin{array}{l}(1.220- \\
1.373)\end{array}$ & $\begin{array}{c}0.7470 \\
{[0.4109-} \\
2.769]\end{array}$ & $\begin{array}{c}0.6152 \\
{[0.5412-} \\
1.008]\end{array}$ & $\begin{array}{c}0.3369 \\
{[0.2642-} \\
0.4856]\end{array}$ & $\begin{array}{l}0.1763^{\$} \\
0.2684^{\#}\end{array}$ & $\begin{array}{l}\text { MCl } \\
\text { Mild } \\
\text { Mod } \\
\text { Sev }\end{array}$ & $\begin{array}{c}- \\
0.8162 \\
0.8176 \\
0.0905\end{array}$ & $\begin{array}{c}- \\
0.4035 \\
0.4916 \\
0.0740\end{array}$ \\
\hline
\end{tabular}

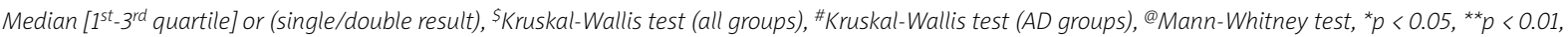
${ }^{* * *} p<0.001$ as compared to unrelated controls; $\left({ }^{*} / * * / * *\right) p$ values as compared to related controls

$U C$ - unrelated controls, $R C$ - related controls, $M C I$ - mild cognitive impairment, Mild - mild AD, Mod-moderate AD, Sev - severe AD, R.U. - relative units

tions in TP53 gene which are common in cancer [45] have been previously reported in the AD animal model [13], and in AD patients may lead to accumulation of damaged DNA [15].

Furthermore, the homo- or heterozygous $A D$ patients with $A P O E$ E4 allele and low apoE levels are most exposed to oxidative modifications and changes in the miR-107 level. The genotypic-phenotypic dependence between APOE E4 variant, apoE concentration and miR-107 level may be confirmed by a negative correlation of the number of E4 alleles and the level of miR-107 in AD patients ( $p=0.009$, $R=-0.448, \mathrm{SCC})$. Similarly to data by Müller et al. [42], in our AD patients, the median miR-107 level decreased with the progression of the disease, most likely due to accumulation of $A \beta$.

However, dissimilar results were obtained in $A D$ patients with the APOE E3/E3 genotype. In those patients, the level of miR-107 increased in the course of $A D$, probably as the response to oxidative stress, 


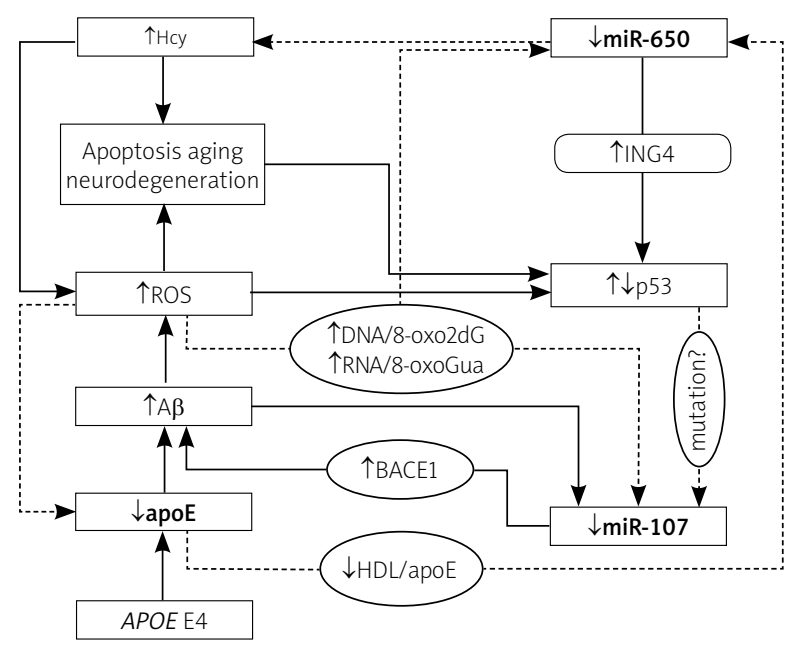

8-oxo2dG-8-oxo-2'-deoxyguanosine, 8-oxoGua-8-oxoguanosine, $A \beta$-amyloid $\beta$, $A P O E$ - apolipoprotein E (gene), apoE - apolipoprotein E, BACE1 - $\beta$-site amyloid precursor protein cleaving enzyme 1, Hcy - homocysteine, HDL/apoE - apoE enriched high-density lipoproteins, ING4 - inhibitor of growth protein 4, miR-107 - hsa-miR-107-5p, miR-650-hsa-miR-650-5p, p53-tumour protein 53, ROS-reactive oxygen species; dotted lines - putative interaction

Fig. 1. Interaction network between apoE, miR-107, miR-650, oxidative stress and cell cycle in Alzheimer's disease.

most likely due to other damage mechanisms than the generation of $A \beta$. The increase in miR-107 in E3/ E3 $A D$ patients may be explained by relatively high apoE plasma content in this group, probably involved in transport of miRNAs via high density lipoproteins (HDL) [67]. It has been shown that HDL molecules, enriched in apoE, may pass through the blood-brain barrier [63], thus facilitating miRNA flux from the brain to periphery and elevate the miRNAs levels in patients plasma, affecting thereby the levels of miR107 as well as different miRNAs, e.g. miR-650.

So far, miR-650 has not been analysed in AD pathology. In the present study the authors performed an in silico analysis to predict whether apoE expression could be managed by miRNAs interference. According to miRWalk 2.0 algorithm, miR-650 could bind to APOE regulating sequence. Moreover, this miRNA was identified in the brain and was shown to affect clinical features of glioblastoma [65].

MiR-650 was previously reported to regulate expression of tumour suppressor protein inhibitor of growth 4 (ING4) in various cancers [75-77]. The ING4 protein is involved in the cell cycle, gene transcription, DNA repair and apoptosis [56] via p53 protein [59]. The overexpression of miR-650 in brain tumours promotes cellular proliferation [65]. Furthermore, the deregulated cell cycle in neurons may be promoted by $\mathrm{p} 38$ mitogen activated protein kinase (MAPK), which is another downstream target of miR-650, mediated by inactivation of ING4 [75]. Interestingly, p38 MAPK has been recently proposed as a new target for therapy of $A D[33,58]$.

The role of miR-650 in AD is unknown. MiR-650 could contribute to development of dementia by regulating the level of biothiols, such as Hcy [12]. Our data indicate that in physiological conditions miR-650 is associated with a decrease in Hcy plasma content $(R=-0.384, p=0.012)$. The neurodegenerative process possibly disturbs these correlations $(p>0.05)$ [49].

It remains unclear whether miR-650 controls apoE production by miRNA interference. The association is disturbed under conditions of oxidative stress in $A D$, perhaps due to their oxidative modifications (Fig. 1). The present research shows that the decrease in plasma apoE concentration is followed by the decrease in miR-650 levels, as a possible effect of this miRNA, similarly to miR-107, being transported in plasma by apoE-enriched HDL molecules.

In $A D$, the relation between the genotype and phenotype of APOE gene and miR-650 expression requires further studies.

\section{Conclusions}

Under physiological conditions, apoE concentration may be regulated by susceptibility for developing $A D$, as confirmed by higher concentration of apoE in controls with a positive family history of AD. Due to diversity of results, further studies are required to provide the final answer on the role of peripheral apoE in the pathogenesis of AD. As in majority of studies, we point to a reduced apoE plasma concentration in the ongoing neurodegenerative disease. Subsequently, in the pathogenesis of $A D$, miRNAs may be also involved. In physiological conditions, both the miR-107 and apoE may regulate the metabolic pathways of $A \beta$ synthesis and clearance, while miR-650 may affect the level of Hcy. These affected metabolic pathways have been reported to be disturbed in the course of development of the neurodegenerative disease (AD). The age of onset in $A D$ patients, the severity of symptoms and the APOE 
genetic variants may influence the regulation of the apoE, miR-107 and miR-650 levels. The strongest relationship between the level of apoE and miRNA seems to occur in patients with disease developing at an early age (60-69 years) and in patients with the most common genotype in population (APOE E3/E3). Moreover, it seems that miR-107 and miR-650 are involved in the pathogenesis of $A D$ in various mechanisms of central lesions, although it is possible that both miRNAs pathways may cross via p53 protein.

\section{Ethics approval and consent to participate}

Written consent was obtained from all participants or their legal guardians. The Bioethical Committee at the Poznan University of Medical Sciences approved the research project by decision no. 1031/13, dated 5 May 2013, with subsequent supplements.

\section{Disclosure}

This work was funded by the grant of the Poznan University of Medical Sciences, no. 502-1401111677-10342.

The authors report no conflict of interest.

\section{References}

1. Arai H, Kashiwagi S, Nagasaka Y, Uchida K, Hoshii Y, Nakamura K. Oxidative modification of apolipoprotein $E$ in human very-low-density lipoprotein and its inhibition by glycosaminoglycans. Arch Biochem Biophys 1999; 367: 1-8.

2. Armstrong RA. Laminar distribution of $\beta$-amyloid $(A \beta)$ peptide deposits in the frontal lobe in familial and sporadic Alzheimer's disease. Folia Neuropathol 2015; 53: 15-23.

3. Balcells I, Cirera S, Busk PK. Specific and sensitive quantitative RT-PCR of miRNAs with DNA primers. BMC Biotechnol 2011; 11: 70.

4. Bales KR, Verina T, Dodel RC, Du Y, Altstiel L, Bender M, Hys lop P, Johnstone EM, Little SP, Cummins DJ, Piccardo P, Ghetti B, Paul SM. Lack of apolipoprotein E dramatically reduces amyloid beta-peptide deposition. Nat Genet 1997; 17: 263-264.

5. Barciszewski J, Barciszewska MZ, Rattan SIS, Clark BFC. The structure and properties of 8-hydroxy-2'-deoxyguanosine - a novel biomarker in aging and carcinogenesis studies. Pol J Chem 1995; 69: 841-851.

6. Castellani RJ, Plascencia-Villa G, Perry G. The amyloid cascade and Alzheimer's disease therapeutics: theory versus observation. Lab Invest 2019 [Epub ahead of print].

7. Chen L, Zhang R, Li P, Liu Y, Qin K, Fa Z, Liu YJ, Ke YQ, Jiang XD. P53-induced microRNA-107 inhibits proliferation of glioma cells and down-regulates the expression of CDK6 and Notch-2. Neurosci Lett 2013; 534: 327-332.
8. Chico L, Simoncini C, Lo Gerfo A, Rocchi A, Petrozzi L, Carlesi C, Volpi L, Tognoni G, Siciliano G, Bonuccelli U. Oxidative stress and APO E polymorphisms in Alzheimer's disease and in mild cognitive impairment. Free Radic Res 2013; 47: 569-576.

9. Czapski GA, Maruszak A, Styczyńska M, Żekanowski C, Safranow K, Strosznajder JB. Association between plasma biomarkers, CDK5 polymorphism and the risk of Alzheimer's disease. Acta Neurobiol Exp (Wars) 2012; 72: 397-411.

10. Dezor M, Dorszewska J, Florczak J, Kempisty B, Jaroszewska-Kolecka J, Rozycka A, Polrolniczak A, Bugaj R, Jagodzinski PP, Kozubski W. Expression of 8-oxoguanine DNA glycosylase 1 (OGG1) and the level of p53 and TNF-alpha proteins in peripheral lymphocytes of patients with Alzheimer's disease. Folia Neuropathol 2011; 49: 123-131.

11. Doecke JD, Laws SM, Faux NG, Wilson W, Burnham SC, Lam C-P, Mondal A, Bedo J, Bush Al, Brown B, De Ruyck K, Ellis KA, Fowler C, Gupta VB, Head R, Macaulay SL, Pertile K, Rowe CC, Rembach A, Rodrigues M, Rumble R, Szoeke C, Taddei K, Taddei T, Trounson B, Ames D, Masters CL, Martins RN; Alzheimer's Disease Neuroimaging Initiative; Australian Imaging Biomarker and Lifestyle Research Group. Blood-based protein biomarkers for diagnosis of Alzheimer disease. Arch Neurol 2012; 69: 13181325.

12. Dorszewska J, Oczkowska A, Prendecki M, Lianeri M, Kozubski W. MTHFR and other enzymes associated with the circulation of methyl in neurodegenerative diseases. In: R. Evans (ed.). Methylenetetrahydrofolate reductase (MTHFR) in health and disease. Nova Science Publishers, UK 2015.

13. Dorszewska J, Oczkowska A, Suwalska M, Rozycka A, Florczak-Wyspianska J, Dezor M, Lianeri M, Jagodzinski PP, Kowalczyk MJ, Prendecki M, Kozubski W. Mutations in the exon 7 of Trp53 gene and the level of p53 protein in double transgenic mouse model of Alzheimer's disease. Folia Neuropathol 2014; 52: $30-40$.

14. Dorszewska J, Prendecki M, Oczkowska A, Dezor M, Kozubski W. Molecular basis of familial and sporadic Alzheimer's disease. Curr Alzheimer Res 2016; 13: 952-963.

15. Dorszewska J, Różycka A, Oczkowska A, Florczak-Wyspiańska J, Prendecki M, Dezor M, Postrach I, Jagodzinski PP, Kozubski W. Mutations of TP53 gene and oxidative stress in Alzheimer's disease patients. Adv Alzheimer's Dis 2014; 3: 24-32.

16. Dubois B, Feldman HH, Jacova C, Dekosky ST, Barberger-Gateau P, Cummings J, Delacourte A, Galasko D, Gauthier S, Jicha G, Meguro K, O’brien J, Pasquier F, Robert P, Rossor M, Salloway S, Stern Y, Visser PJ, Scheltens P. Research criteria for the diagnosis of Alzheimer's disease: revising the NINCDS-ADRDA criteria. Lancet Neurol 2007; 6: 734-746.

17. Fagan AM, Mintun MA, Mach RH, Lee S-Y, Dence CS, Shah AR, LaRossa GN, Spinner ML, Klunk WE, Mathis CA, DeKosky ST, Morris JC, Holtzman DM. Inverse relation between in vivo amyloid imaging load and cerebrospinal fluid A 42 in humans. Ann Neurol 2006; 59: 512-519.

18. Fan P, Liu Y, Zhang Z, Liu B, Ge W, Ye S, Cheng Y, Chen J. Serum apolipoprotein A I, B100 and E levels and apolipoprotein E polymorphism in patients with Alzheimer's disease and multiple infarction dementia in Chinese population. Hua Xi Yi Ke Da Xue Xue Bao 2001; 32: 389-391. 
19. Filipek-GliszczyńskaA, BarczakA, BudziszewskaM, MandeckaM, Gabryelewicz T, Barcikowska M. The Erlangen Score Algorithm in the diagnosis and prediction of the progression from subjective cognitive decline and mild cognitive impairment to Alzheimer-type dementia. Folia Neuropathol 2018; 56: 88-96.

20. Guo L-H, Alexopoulos P, Wagenpfeil S, Kurz A, Perneczky R, Alzheimer's Disease Neuroimaging Initiative R. Plasma proteomics for the identification of Alzheimer disease. Alzheimer Dis Assoc Disord 2013; 27: 337-342

21. Gupta P, Bhattacharjee S, Sharma AR, Sharma G, Lee S-S, Chakraborty C. miRNAs in Alzheimer disease - a therapeutic perspective. Curr Alzheimer Res 2017; 14: 1198-11206.

22. Gupta VB, Laws SM, Villemagne VL, Ames D, Bush Al, Ellis KA, Lui JK, Masters C, Rowe CC, Szoeke C, Taddei K, Martins RN AIBL Research Group. Plasma apolipoprotein E and Alzheimer disease risk: The AIBL study of aging. Neurology 2011; 76: 1091 1098

23. Hodgson N, Trivedi M, Muratore C, Li S, Deth R. Soluble oligomers of amyloid- cause changes in redox state, DNA methylation, and gene transcription by inhibiting EAAT3 mediated cysteine uptake. J Alzheimers Dis 2013; 36: 197-209.

24. Holtzman DM, Fagan AM, Mackey B, Tenkova T, Sartorius L, Paul SM, Ann Neurol 2000; 47: 739-747. Apolipoprotein E facilitates neuritic and cerebrovascular plaque formation in an Alzheimer's disease model. Ann Neurol 2000; 47: 739-747.

25. Hu WT, Holtzman DM, Fagan AM, Shaw LM, Perrin R, Arnold SE, Grossman M, Xiong C, Craig-Schapiro R, Clark CM, Pickering E, Kuhn M, Chen Y, Van Deerlin VM, McCluskey L, Elman L, Karlawish J, Chen-Plotkin A, Hurtig HI, Siderowf A, Swenson F, Lee VM, Morris JC, Trojanowski JQ, Soares H; Alzheimer's Disease Neuroimaging Initiative. Plasma multianalyte profiling in mild cognitive impairment and Alzheimer disease. Neurology 2012; 79: 897-905

26. Hye A, Riddoch-Contreras J, Baird AL, Ashton NJ, Bazenet C, Leung R, Westman E, Simmons A, Dobson R, Sattlecker M, Lupton M, Lunnon K, Keohane A, Ward M, Pike I, Zucht HD, Pepin D, Zheng W, Tunnicliffe A, Richardson J, Gauthier S, Soininen H, Kłoszewska I, Mecocci P, Tsolaki M, Vellas B, Lovestone S. Plasma proteins predict conversion to dementia from prodromal disease. Alzheimers Dement 2014; 10: 799-807.e2.

27. Hyman BT, Holtzman DM. Apolipoprotein E levels and Alzheimer risk. Ann Neurol 2015; 77: 204-205.

28. Jack CR, Bennett DA, Blennow K, Carrillo MC, Dunn B, Haeberlein SB, Holtzman DM, Jagust W, Jessen F, Karlawish J, Liu E, Molinuevo JL, Montine T, Phelps C, Rankin KP, Rowe CC, Scheltens P, Siemers E, Snyder HM, Sperling R; Contributors. NIA-AA Research Framework: Toward a biological definition of Alzheimer's disease. Alzheimers Dement 2018; 14: 535-562.

29. Johnstone D, Milward EA, Berretta R, Moscato P, Alzheimer's Disease Neuroimaging Initiative for the ADN. Multivariate protein signatures of pre-clinical Alzheimer's disease in the Alzheimer's disease neuroimaging initiative (ADNI) plasma proteome dataset. PLoS One 2012; 7: e34341.

30. Koch M, Jensen MK. HDL-cholesterol and apolipoproteins in relation to dementia. Curr Opin Lipidol 2016; 27: 76-87.
31. Krokan HE, Kavli B, Slupphaug G. Novel aspects of macromolecular repair and relationship to human disease. J Mol Med 2004; 82: 280-297.

32. Kuo Y-M, Emmerling MR, Bisgaier CL, Essenburg AD, Lampert HC, Drumm D, Roher AE. Elevated low-density lipoprotein in Alzheimer's disease correlates with brain A $\beta$ 1-42 levels. Biochem Biophys Res Commun 1998; 252: 711-715.

33. Lee JK, Kim N-J. Recent Advances in the Inhibition of p38 MAPK as a potential strategy for the treatment of Alzheimer's disease. Molecules 2017; 22: 1287.

34. Leidinger P, Backes C, Deutscher S, Schmitt K, Mueller SC, Frese K, Haas J, Ruprecht K, Paul F, Stähler C, Lang CJ, Meder B, Bartfai T, Meese E, Keller A. A blood based 12-miRNA signature of Alzheimer disease patients. Genome Biol 2013; 14: R78.

35. Li JJ, Dolios G, Wang R, Liao F-F. Soluble beta-amyloid peptides, but not insoluble fibrils, have specific effect on neuronal microRNA expression. PLoS One 2014; 9: e90770.

36. Limon-Sztencel A, Lipska-Ziętkiewicz BS, Chmara M, Wasag B, Bidzan L, Godlewska BR, Limon J. The algorithm for Alzheimer risk assessment based on APOE promoter polymorphisms. Alzheimers Res Ther 2016; 8: 19.

37. Liu C-C, Liu C-C, Kanekiyo T, Xu H, Bu G. Apolipoprotein E and Alzheimer disease: risk, mechanisms and therapy. Nat Rev Neurol 2013; 9: 106-118.

38. Liu D, Xu Y. p53, oxidative stress, and aging. Antioxid Redox Signal 2011; 15: 1669-1678.

39. Łojkowska W, Witkowski G, Bednarska-Makaruk M, Wehr H, Sienkiewicz-Jarosz H, Graban A, Bochyńska A, Wiśniewska A, Gugała M, Sławińska K, Sawicka B, Poniatowska R, Ryglewicz D. Correlations between cerebellar and brain volumes, cognitive impairments, ApoE levels, and APOE genotypes in patients with AD and MCl. Curr Alzheimer Res 2013; 10: 964-972.

40. Maruszak A, Żekanowski C. Mitochondrial dysfunction and Alzheimer's disease. Prog Neuro-Psychopharmacology Biol Psychiatry 2011; 35: 320-330.

41. Maślińska D, Laure-Kamionowska M, Szukiewicz D, Maśliński S, Księżopolska-Orłowska K. Commitment of protein p53 and amyloid-beta peptide $(A \beta)$ in aging of human cerebellum. Folia Neuropathol 2017; 2: 161-167.

42. Müller M, Kuiperij HB, Claassen JA, Küsters B, Verbeek MM. MicroRNAs in Alzheimer's disease: differential expression in hippocampus and cell-free cerebrospinal fluid. Neurobiol Aging 2014; 35: 152-158.

43. Nelson PT, Wang W-X. MiR-107 is reduced in Alzheimer's disease brain neocortex: validation study. J Alzheimers Dis 2010; 21: 75-79.

44. Nesteruk M, Nesteruk T, Styczyńska M, Mandecka M, Barczak A, Barcikowska M. Combined use of biochemical and volumetric biomarkers to assess the risk of conversion of mild cognitive impairment to Alzheimer's disease. Folia Neuropathol 2016; 4: 369-374.

45. Nixon DW. The inverse relationship between cancer and Alzheimer's disease: a possible mechanism. Curr Alzheimer Res 2017; 14: 883-893.

46. Panza F, Solfrizzi V, Colacicco AM, Basile AM, D'Introno A, Capurso C, Sabba M, Capurso S, Capurso A. Apolipoprotein E (APOE) polymorphism influences serum APOE levels in Alzheimer's 
disease patients and centenarians. Neuroreport 2003; 14: 605 608.

47. Pluta R, Ułamek-Kozioł M, Januszewski S, Czuczwar SJ. Platelets, lymphocytes and erythrocytes from Alzheimer's disease patients: the quest for blood cell-based biomarkers. Folia Neuropathol 2018; 56: 14-20.

48. Prendecki M, Dorszewska J. The role of microRNA in the pathogenesis and diagnosis of neurodegenerative diseases. Austin Alzheimers Parks Dis 2014; 1: 1-10.

49. Prendecki M, Florczak-Wyspianska J, Kowalska M, Ilkowski J, Grzelak T, Bialas K, Wiszniewska M, Kozubski W, Dorszewska J. Biothiols and oxidative stress markers and polymorphisms of TOMM40 and APOC1 genes in Alzheimer's disease patients. Oncotarget 2018; 9: 35207-35225.

50. Prendecki M, Florczak-Wyspianska J, Kowalska M, Lianeri M, Kozubski W, Dorszewska J. Normal aging and dementia. In: Update on Dementia. InTech, Rijeka 2016.

51. Rasmussen KL, Tybjaerg-Hansen A, Nordestgaard BG, Frikke-Schmidt R. Plasma levels of apolipoprotein $E$ and risk of dementia in the general population. Ann Neurol 2015; 77: 301 311.

52. Rasmussen KL, Tybjærg-Hansen A, Nordestgaard BG, Frikke-Schmidt R. Plasma apolipoprotein $E$ levels and risk of dementia: A Mendelian randomization study of 106,562 individuals. Alzheimers Dement 2018; 14: 71-80.

53. Rezeli M, Zetterberg H, Blennow K, Brinkmalm A, Laurell T, Hansson O, Marko-Varga G. Quantification of total apolipoprotein $\mathrm{E}$ and its specific isoforms in cerebrospinal fluid and blood in Alzheimer's disease and other neurodegenerative diseases. EuPA Open Proteomics 2015; 8: 137-143.

54. Roberts TC, Coenen-Stass AML, Wood MJA. Assessment of RT-qPCR normalization strategies for accurate quantification of extracellular microRNAs in murine serum. PLoS One 2014; 9: e89237.

55. Roks G, Cruts M, Houwing-Duistermaat JJ, Dermaut B, Serneels S, Havekes LM, Hofman A, Breteler MM, Van Broeckhoven C, van Duijn CM. Effect of the APOE-491A/T promoter polymorphism on apolipoprotein E levels and risk of Alzheimer disease: The Rotterdam Study. Am J Med Genet 2002; 114: 570-573.

56. Russell M, Berardi P, Gong W, Riabowol K. Grow-ING, Age-ING and Die-ING: ING proteins link cancer, senescence and apoptosis. Exp Cell Res 2006; 312: 951-961.

57. Scacchi R, Gambina G, Ruggeri M, Martini MC, Ferrari G, Silvestri M, Schiavon R, Corbo RM. Plasma levels of apolipoprotein E and genetic markers in elderly patients with Alzheimer's disease. Neurosci Lett 1999; 259: 33-36.

58. Shen JN, Xu LX, Shan L, Zhang WD, Li HL, Wang R. Neuroprotection of (+)-2-(1-hydroxyl-4-oxocyclohexyl) ethyl caffeate against hydrogen peroxide and lipopolysaccharide induced injury via modulating arachidonic acid network and p38-MAPK signaling. Curr Alzheimer Res 2015; 12: 892-902.

59. Shiseki M, Nagashima M, Pedeux RM, Kitahama-Shiseki M, Miura K, Okamura S, Onogi H, Higashimoto Y, Appella E, Yokota J, Harris CC. p29ING4 and p28ING5 bind to p53 and p300, and enhance p53 activity. Cancer Res 2003; 63: 2373-2378.

60. Siest G, Bertrand P, Qin B, Herbeth B, Serot JM, Masana L, Ribalta J, Passmore AP, Evans A, Ferrari M, Franceschi M, Shepherd J,
Cuchel M, Beisiegel U, Zuchowsky K, Rukavina AS, Sertic J, Stojanov M, Kostic V, Mitrevski A, Petrova V, Sass C, Merched A, Salonen JT, Tiret L, Visvikis S. Apolipoprotein E polymorphism and serum concentration in Alzheimer's disease in nine European centres: the ApoEurope study. ApoEurope group. Clin Chem Lab Med 2000; 38: 721-730.

61. Simon R, Girod M, Fonbonne C, Salvador A, Clément Y, Lantéri P, Amouyel P, Lambert JC, Lemoine J. Total ApoE and ApoE4 isoform assays in an Alzheimer's disease case-control study by targeted mass spectrometry $(n=669)$ : A pilot assay for methionine-containing proteotypic peptides. Mol Cell Proteomics 2012; 11: 1389-1403.

62. Song F, Poljak A, Crawford J, Kochan NA, Wen W, Cameron B, Lux O, Brodaty H, Mather K, Smythe GA, Sachdev PS. Plasma apolipoprotein levels are associated with cognitive status and decline in a community cohort of older individuals. PLoS One 2012; 7: e34078.

63. Song Q, Song H, Xu J, Huang J, Hu M, Gu X, Chen J, Zheng G, Chen $H$, Gao X. Biomimetic apoE-reconstituted high density lipoprotein nanocarrier for blood-brain barrier penetration and amyloid beta-targeting drug delivery. Mol Pharm 2016; 13 : 3976-3987.

64. Stratman NC, Castle CK, Taylor BM, Epps DE, Melchior GW, Carter DB. Isoform-specific interactions of human apolipoprotein $E$ to an intermediate conformation of human Alzheimer amyloid-beta peptide. Chem Phys Lipids 2005; 137: 52-61.

65. Sun B, Pu B, Chu D, Chu X, Li W, Wei D. MicroRNA-650 expression in glioma is associated with prognosis of patients. J Neurooncol 2013; 115: 375-380.

66. Taddei K, Clarnette R, Gandy SE, Martins RN. Increased plasma apolipoprotein E (apoE) levels in Alzheimer's disease. Neurosci Lett 1997; 223: 29-32.

67. Vickers KC, Palmisano BT, Shoucri BM, Shamburek RD, Remaley AT. MicroRNAs are transported in plasma and delivered to recipient cells by high-density lipoproteins. Nat Cell Biol 2011; 13: 423-433.

68. Wang C, Yu JT, Wang HF, Jiang T, Tan CC, Meng XF, Soares HD, Tan L. Meta-analysis of peripheral blood apolipoprotein E levels in Alzheimer's disease. PLoS One 2014; 9: e89041.

69. Wang J-X, Gao J, Ding S-L, Wang K, Jiao J-Q, Wang Y, Sun T, Zhou LY, Long B, Zhang XJ, Li Q, Liu JP, Feng C, Liu J, Gong Y, Zhou Z, Li PF. Oxidative modification of miR-184 enables it to target BCl-xL and BCl-w. Mol Cell 2015; 59: 50-61.

70. Wang T, Chen K, Li H, Dong S, Su N, Liu Y, Cheng Y, Dai J, Yang C, Xiao S. The feasibility of utilizing plasma miRNA107 and BACE1 messenger RNA gene expression for clinical diagnosis of amnestic mild cognitive impairment. J Clin Psychiatry 2015; 76 : 135-141.

71. Wang W-X, Rajeev BW, Stromberg AJ, Ren N, Tang G, Huang Q, Rigoutsos I, Nelson PT. The expression of microRNA miR-107 decreases early in Alzheimer's disease and may accelerate disease progression through regulation of beta-site amyloid precursor protein-cleaving enzyme 1. J Neurosci 2008; 28: 12131223.

72. Wolters FJ, Koudstaal PJ, Hofman A, van Duijn CM, Ikram MA. Serum apolipoprotein $\mathrm{E}$ is associated with long-term risk of 
Michal Prendecki, Jolanta Florczak-Wyspianska, Marta Kowalska, Jan Ilkowski, Teresa Grzelak, Katarzyna Bialas, Wojciech Kozubski, Jolanta Dorszewska

Alzheimer's disease: The Rotterdam Study. Neurosci Lett 2016; 617: 139-142.

73. Xu S, Zhang R, Niu J, Cui D, Xie B, Zhang B, Lu K, Yu W, Wang X, Zhang Q. Oxidative stress mediated-alterations of the microRNA expression profile in mouse hippocampal neurons. Int J Mol Sc 2012; 13: 16945-16960.

74. Yılmaz ŞG, Erdal ME, Özge AA, Sungur MA. Can peripheral microRNA expression data serve as epigenomic (upstream) biomarkers of Alzheimer's disease? Omi A J Integr Biol 2016; 20: 456-461.

75. You Q, Li H, Liu Y, Xu Y, Miao S, Yao G, Xue Y, Geng J, Jin X, Meng H. MicroRNA-650 targets inhibitor of growth 4 to promote colorectal cancer progression via mitogen activated protein kinase signaling. Oncol Lett 2018; 16: 2326-2334.

76. Zeng Z, Li F, Gao F, Sun D, Yao L. Upregulation of miR-650 is correlated with down-regulation of ING4 and progression of hepatocellular carcinoma. J Surg Oncol 2013; 107: 105-110.

77. Zhang X, Zhu W, Zhang J, Huo S, Zhou L, Gu Z, Zhang M. MicroR NA-650 targets ING4 to promote gastric cancer tumorigenicity. Biochem Biophys Res Commun 2010; 395: 275-280. 